\title{
Developmental Activation of the Proteolipid Protein Promoter Transgene in Neuronal and Oligodendroglial Cells of Neostriatum in Mice
}

\author{
Daniel Fulton ${ }^{a, b}$ Pablo Paez ${ }^{a}$ Vilma Spreur ${ }^{a}$ Vance Handley ${ }^{a}$ \\ Christopher S. Colwell ${ }^{\mathrm{a}}$ Anthony Campagnoni ${ }^{\mathrm{a}}$ Robin Fisher $^{\mathrm{a}}$ \\ ${ }^{a}$ Developmental and Molecular Neuroscience Group, Intellectual Development and Disabilities Research Center, \\ Neuropsychiatric Institute, School of Medicine, The University of California at Los Angeles, Los Angeles, Calif., USA; \\ bSchool of Life Sciences, The University of Warwick, Coventry, UK
}

\section{Key Words}

Myelin proteins $\cdot$ EGFP reporter $\cdot$ Soma-restricted and classic proteolipid protein isoforms $\cdot$ Cell lineage markers in immature neostriatum - Morphogenesis . Electrophysiological development $\cdot$ Basal ganglia

\begin{abstract}
Prior studies suggest that non-canonical proteolipid protein (PLP) gene expression occurs during development in nonmyelinating neurons as well as myelinating oligodendroglia in mammalian brain. To assess this possibility in neostriatum, a region of uncertain PLP gene expression in neurons, morphological and electrophysiological tools were used to determine phenotypes of cells with activation of a PLP promoter transgene during the early postnatal period in mice. PLP gene expression is evident in both neuronal and oligodendroglial phenotypes in developing neostriatum, a conclusion based on three novel observations: (1) An enhanced green fluorescent protein (EGFP) reporter of PLP promoter activation was localized in two distinct populations of cells, which exhibit collective, developmental differences of morphological and electrophysiological characteristics in accord with neuronal and oligodendroglial phenotypes of neostriatal cells found during the early postnatal period in both transgenic and wild-type mice. (2) The EGFP reporter of
\end{abstract}

PLP promoter activation was appropriately positioned to serve as a regulator of $P L P$ gene expression. It colocalized with native PLP proteins in both neuronal and oligodendroglial phenotypes; however, only soma-restricted PLP protein isoforms were found in the neuronal phenotype, while classic and soma-restricted PLP protein isoforms were found in the oligodendroglial phenotype. (3) As shown by EGFP reporter, $P L P$ promoter activation was placed to regulate $P L P$ gene expression in only one neuronal phenotype among the several that constitute neostriatum. It was localized in medium spiny neurons, but not large aspiny neurons. These outcomes have significant implications for the non-canonical functional roles of $P L P$ gene expression in addition to myelinogenesis in mammalian brain, and are consistent with potentially independent pathologic loci in neurons during the course of human mutational disorders of PLP gene expression.

Copyright $\odot 2011$ S. Karger AG, Basel

\section{Introduction}

Alternative splicing of the proteolipid protein (PLP) gene encodes two main 'classic' protein isoforms, PLP and DM20, constituents in myelin membrane of oligodendroglia that may have additional functions suggest-

\section{KARGER}

(C) 2011 S. Karger AG, Basel

Fax +41613061234 E-Mail karger@karger.ch www.karger.com
Accessible online at: www.karger.com/dne
Prof. Robin Fisher

Room 301, Neuroscience Research Building

School of Medicine, The University of California at Los Angeles

635 Charles Young Drive South, Los Angeles, CA 90095 (USA)

Tel. +1 310206 9360, E-Mail rfisher@ mednet.ucla.edu 
ed by localization in neural precursors $[1,2]$, myocardium, spermatozoa, and thymus [3-7]. In mice, alternative splicing of the cryptic 1.1 exon of the PLP gene also encodes two 'soma-restricted' protein isoforms, sr-PLP and sr-DM20, expressed by both neurons and oligodendroglia and associated with trafficking/recycling of endocytotic vesicles [8-11]. As shown by immunohistochemistry, neuronal expression of sr-isoforms (collectively termed sr-PLP) is complicated by distinct dense versus (vs.) sparse patterns of intracellular label accumulation in various neuronal populations and brain sites, particularly during early postnatal development [10]. Despite substantial evidence for label specificity, sparsely labeled sr-PLP neurons are so numerous and widely distributed that their occurrence remains questionable, and they have received little experimental attention.

Mutant mice that localize enhanced green fluorescent protein (EGFP) reporter under control of activated PLP promoter transgenes now allow this problem to be addressed with alternative, intrinsically generated molecular probes that can lead and signify PLP gene expression with fewer technical difficulties than immunohistochemical detection of low levels of native proteins [12]. In this report, we test the hypothesis that oligodendroglia, but not neurons, activate a PLP gene promoter (EGFP+ vs. EGFP- cells of respective lineage phenotypes) in neostriatum, a brain site that before and during myelinogenesis contains both densely labeled PLP and sr-PLP cells (possible oligodendroglia) and sparsely labeled sr-PLP cells (possible premyelinating stages of oligodendroglia and/or neurons) [pers. obs., 10]. The investigated period is early postnatal development, when the label density distinction is established for sr-PLP cells. The outcome may be clinically relevant - duplicative mutations of human PLP1 gene in Pelizaeus-Merzbacher X-linked leukodystrophy (PMD) lead to progressive dysmyelination and neuronal degeneration in striatonigral components of basal ganglia $[10,13,14]$. Improved realization of the regional and cellular neuroanatomy of $P L P$ gene expression may also contribute to uncovering the true range of its functional roles. For example, medullary neurons in myelin-deficient mutant rats accumulate abnormal PLP proteins, which disrupt potassium channels, alter rhythmic function of central pattern generators and yield lethal respiratory dysfunction $[15,16]$.

\section{Methods}

Animal use protocols were approved by the UCLA Animal Research Committee consistent with guidelines of the National Institutes of Health. Acute experiments were performed on brain slices obtained from homozygous male and female transgenic mice (founder genotype, EGFP10 with high levels of reporter expression, shown by Southern blots, progeny genotype shown by positive generation of EGFP reporter in brain under control of a known PLP promoter sequence [see 12 for construct details]). Observations were obtained from 51 mice (4-16 days of postnatal age, $\mathrm{P} 4-\mathrm{P} 16)$ in electrophysiological studies, 21 mice (P4-P20) in immunohistochemical studies, and materials from our anatomical collection. As detailed elsewhere [17], acute slices for electrophysiological recording were prepared from brains of mice anesthetized with isoflurane, decapitated and brains removed and placed rapidly in ice-cold, oxygenated slicing solution. Coronal slices (300 $\mu \mathrm{m}$ thickness) were cut by Vibratome, stored in oxygenated bicarbonate buffer recording solution (BBS) at $30^{\circ} \mathrm{C}$ for $30 \mathrm{~min}$, then stored at room temperature (RT) before experiments.

Slicing solution contained (in $\mathrm{mM}$ ): $26 \mathrm{NaHCO}_{3}, 1.25$ $\mathrm{NaH}_{2} \mathrm{PO}_{4}, 10$ glucose, $125 \mathrm{NaCl}, 3 \mathrm{KCl}, 5 \mathrm{MgCl}_{2}, 1 \mathrm{CaCl}_{2}$. BBS contained (in mM): $26 \mathrm{NaHCO}_{3}, 1.25 \mathrm{NaH}_{2} \mathrm{PO}_{4}, 10$ glucose, 125 $\mathrm{NaCl}, 3 \mathrm{KCl}, 2 \mathrm{MgCl}_{2}, 2 \mathrm{CaCl}_{2}$. These solutions were bubbled with $95 \% 0_{2} / 5 \% \mathrm{CO}_{2}$ at $\mathrm{RT}\left(20-23^{\circ} \mathrm{C}\right)$, with $\mathrm{pH}$ and osmolarity adjusted to 7.3 and $300-310 \mathrm{~mm} / \mathrm{kg}$, respectively. Voltage and current clamp recordings used a $\mathrm{K}^{+}$-based electrode solution that contained (in $\mathrm{mM}$ ): $112.5 \mathrm{~K}$-gluconate, $4 \mathrm{NaCl}, 17.5 \mathrm{KCl}, 0.5 \mathrm{CaCl}_{2}$, $1 \mathrm{MgCl}_{2}, 0.5 \mathrm{Mg}$-ATP, 0.05 EGTA, $1 \mathrm{Na}$-HEPES, 0.1 tris-GTP, 0.1 leupeptin, 0.5 phosphocreatine (di-tris). The electrode solution also contained biocytin (0.05\%), with $\mathrm{pH}$ and osmolarity adjusted to 7.2 and $290 \mathrm{~mm} / \mathrm{kg}$, respectively. Tetrodotoxin (Sigma-Aldrich, St. Louis, Mo., USA) stock solution was prepared in distilled water $(1 \mathrm{mM})$, and diluted to a final concentration of $1-0.5 \mu \mathrm{M}$ in BBS. 6-cyano-7-nitroquinoxaline-2,3-dione (CNQX, Sigma-Aldrich) stock solution was prepared in dimethyl sulfoxide $(20 \mathrm{mM})$, and diluted to a final concentration of $20 \mu \mathrm{M}$ in BBS. Both drugs were applied to slices via the perfusion system.

EGFP+ cells in neostriatum were identified by epifluorescent illumination for patch clamp recording, and $G \Omega$ seals were obtained under visual control by differential interference contrast illumination [17]. Recording pipettes (3-6 M $\Omega$ ) were made from glass capillary tubes (World Precision Instruments, Sarasota, Fla., USA) filled with $\mathrm{K}^{+}$-based electrode solution (junction potenti$\mathrm{al}=12 \mathrm{mV}$, corrected off-line). Signals were amplified by an Axopatch 1D amplifier (Molecular Devices, Sunnyvale, Calif., USA), digitized at $10 \mathrm{kHz}$ and filtered at $5 \mathrm{kHz}$. Signals were grounded with an $\mathrm{AgCl}$ bath electrode, and data acquisition was performed with pClamp version 9.0 (Molecular Devices). Cell membrane and recording parameters (capacitance, input resistance, access resistance, holding current, via pClamp) were monitored regularly during each experiment. In voltage clamp experiments, data were discarded if cells displayed access resistances $\geq 30 \mathrm{M} \Omega$. Mean (+ standard error of the mean, X + SEM) access resistances for neostriatal neurons were: single action potential $(\mathrm{AP})=20.04$ $\pm 1.31 \mathrm{M} \Omega$ and multiple $\mathrm{AP}=20.88 \pm 0.80 \mathrm{M} \Omega$. Series resistance compensation was not applied, and leak and capacitance currents were subtracted digitally during voltage clamp using a $\mathrm{P} / \mathrm{N}$ protocol. $\mathrm{Na}^{+}$and $\mathrm{K}^{+}$currents were activated from a holding potential of $-82 \mathrm{mV}$ with a series of depolarizing voltage commands (-82 
to $+58 \mathrm{mV}, 10 \mathrm{mV}$ steps with a duration of $150 \mathrm{~ms})$. Spontaneous excitatory postsynaptic currents (sEPSCs) were recorded at holding potential of $-82 \mathrm{mV}$ in BBS, and analyzed off-line using MiniAnalysis (Synaptosoft Inc., Fort Lee, N.J., USA). Current-voltage (I-V) relationships, AP thresholds, kinetics and after-hyperpolarizations (AHPs) were determined for current clamp experiments by a pulse protocol series of depolarizing current steps ( -0.1 to 0.2 $\mathrm{nA}, 0.1 \mathrm{nA}$ steps, $150 \mathrm{~ms}$ duration).

For immunohistochemical preparations and analyses of patch-clamped cells, tissue was fixed by immersion in $4 \%$ paraformaldehyde, blocked and permeabilized in phosphate-buffered saline (PBS) containing 10\% normal goat serum (NGS) and $0.2 \%$ Triton X100, and incubated overnight $\left(4^{\circ} \mathrm{C}\right.$ with agitation) in primary antibodies diluted in PBS with $10 \%$ NGS (carrier) [17]. Slices were subsequently washed in PBS with $0.01 \%$ Triton X100, incubated in secondary antibody diluted in carrier (4-6 h, 1:800, RT with agitation), rinsed, and incubated in streptavidin-AMCA for detection of biocytin-filled cells (2 h, 1:400, RT with agitation; Vector Laboratories Inc., Burlingame, Calif., USA). Sections were air dried, mounted on glass slides and coverslipped with aqueous media (Aquamount, Lerner Laboratories, Pittsburgh, Pa., USA; EGFP was an intrinsic fluorescent label that could be visualized in aqueous media mounts on glass slides, with coverslips). The following primary antibodies were tested: mouse monoclonal anti-NeuN (1:800, Millipore, Billerica, Mass., USA); mouse monoclonal anti-MAP2 AP-20 clone (1:800, Sigma-Aldrich); rabbit monoclonal anti-DARPP-32 (1:400, Cell Signaling Technology, Boston, Mass., USA); rabbit polyconal anti-NG2 (1:300, Millipore), rat monoclonal anti-PDGFR $\alpha$ (1:200, BD Biosciences, San Jose, Calif., USA); rat anti-PLP/DM20 clone AA3 (gift from Steven Pfeiffer, University of Connecticut Health Science Center, Conn., USA); rabbit polyconal anti-srPLP (1:400). For sequential, multiple labeling studies, immunolabeling of primary antibodies was also produced by Alexa Fluor ${ }^{\circledR}-594$ conjugated goat IgG antibodies raised against appropriate host species (Invitrogen, San Diego, Calif., USA). In all cases, specific labeling was abolished when these antibodies were deleted from primary incubation. Images were acquired with an inverted microscope (Olympus IX81) equipped with a spinning disc confocal setup.

Biocytin-filled cells were labeled, then characterized by photomicrography and camera lucida drawings [17]. Digital photomicrographs of cells were derived from $35-\mathrm{mm}$ color slide film (Nikon Inc., Melville, N.Y., USA).

For immunohistochemistry on perfusion-fixed tissue sections, mice were deeply anesthetized with sodium pentobarbital and perfused transcardially with ice-cold $4 \%$ paraformaldehyde. Brains were postfixed overnight, mounted in agarose, and sectioned in the coronal plane (50 $\mu \mathrm{m}$ thickness) by Vibratome. Methods for immunolabeling these sections were similar to those for thick slices with alterations in blocking/permeabilization solution ( $0.1 \%$ Triton X100 and 2\% NGS), reduced duration of blocking step ( $2 \mathrm{~h} \mathrm{RT})$, and reduced duration of incubation in secondary antibody (1.5 h RT) [17].

Quantitative measurements of EGFP+ and immunoreactive cells were based on cell counts from confocal images acquired and displayed in SlideBook ${ }^{\mathrm{TM}} 4.0$ software (Intelligent Imaging Innovations, Inc., Denver, Colo., USA). Three sections were analyzed for each condition, with counts obtained from six individual fields in each section. Positive cell counts were checked by examination of immunolabel and EGFP signal in multiple optical sec- tions. Classic PLP expression was quantified using SlideBook ${ }^{\mathrm{TM}}$ 4.0 software. EGFP+ cells were selected in regions of interest, and software was used to measure average PLP signal intensity. Electrophysiological data were analyzed using Clampfit 8 (Molecular Devices). Prior to current measurement, traces were normalized to the average holding current from the period preceding the voltage step. $\mathrm{Na}^{+}$currents were measured as peak inward response evoked during the first $10 \mathrm{~ms}$ of a depolarizing step to $-22 \mathrm{mV} . \mathrm{K}^{+}$ currents were measured during the steady-state phase between 100 and $150 \mathrm{~ms}$ after onset of a depolarizing voltage command to $+58 \mathrm{mV}$. AP slope and half-width were measured using pClamp, while AP and sEPSC frequencies were analyzed with Mini-Analysis. Normal distributions were tested in each data set using Kolmogorov-Smirnov tests. For data with normal distributions, single between-group comparisons were made by tests, and multiple comparisons were investigated by one-way ANOVA followed by Bonferroni's multiple comparison tests to detect pair-wise between-group differences. When normal distributions were absent, nonparametric Mann-Whitney U tests were used to make comparisons, and Kruskal-Wallis tests were used for multiple group comparisons, with between-group differences checked by Dunn's multiple comparisons test. All statistical tests were computed with Prism 4.0 for Macintosh (Graphpad Software, Inc., El Camino Real, Calif., USA). A fixed value of $\mathrm{p}_{\alpha}<0.05$ for onetailed tests was the criterion for reliable differences between groups. Cited values were Xs + SEMs unless otherwise noted.

\section{Results}

\section{Morphological Characteristics of Neostriatal Cells with Activated PLP Promoter}

EGFP+ cells with activated PLP promoter were widely distributed throughout immature forebrain throughout the period of development under investigation. At the beginning of this period (surveyed at low magnification for a P6 transgenic mouse in fig. 1), these cells were particularly prominent within neostriatum due to their close compaction and extensive distribution across the entire thickness of sections and slices. They had comparable arrangements and high cellular density throughout neostriatum. No consistent evidence of macroscopic 'striasomal' (i.e. cell island vs. matrix) compartmentation was seen in serial sections. At this early age, fiber fascicles of the internal capsule were clearly apparent in neostriatum, but contained few EGFP+ cells, consistent with their coincident low density of interfascicular oligodendroglia and paucity of myelin.

Neostriatal EGFP+ cells were categorized into three interspersed structural groups at this early postnatal stage: group I constituted the majority of EGFP+ cells, with spherical cell bodies and medium (sized) diameters $>10 \mu \mathrm{m}$. Group II had bipolar (spindle-shaped) cell bodies and small diameters $<10$ (mostly 7-8) $\mu \mathrm{m}$. Group III 

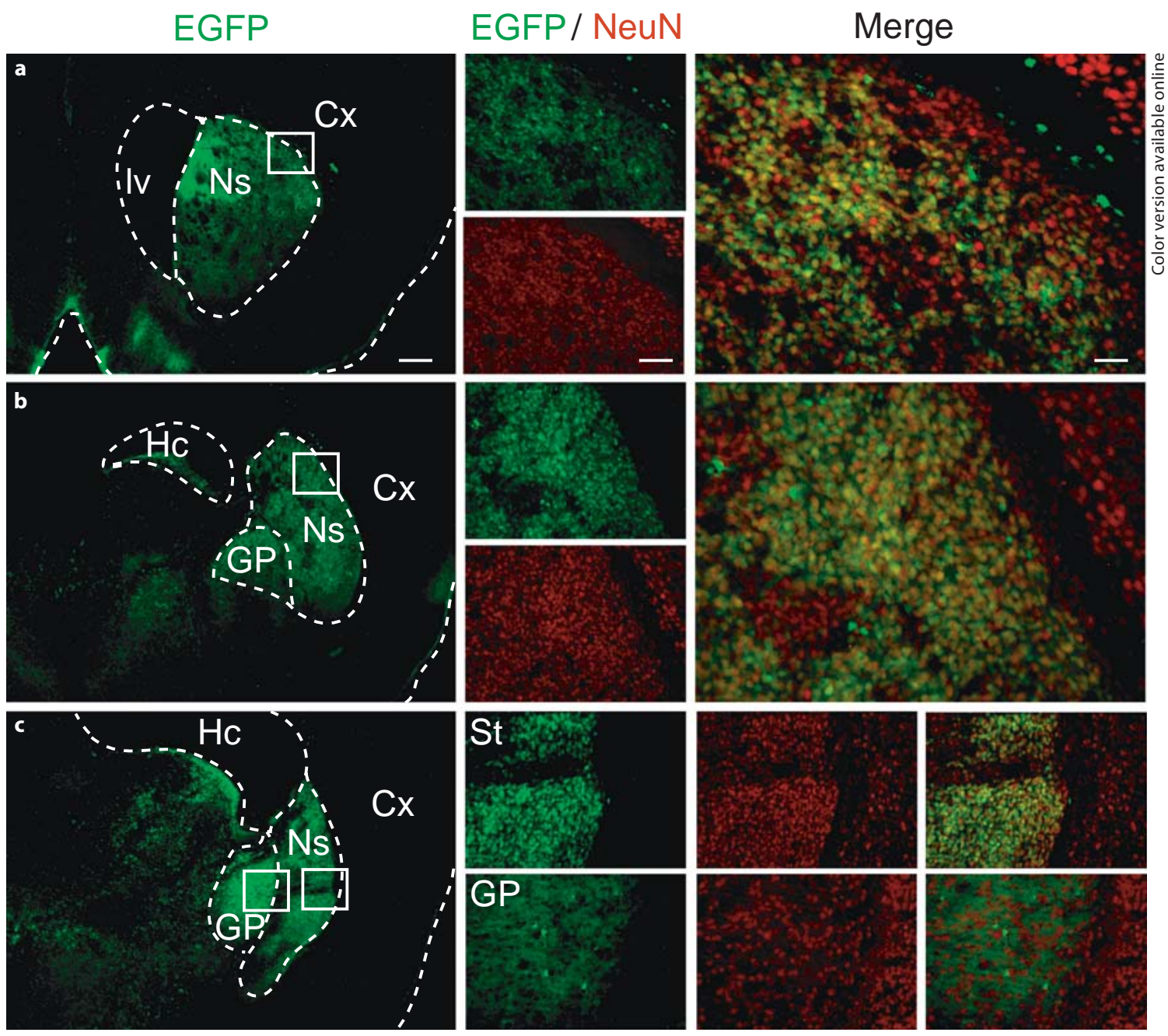

Fig. 1. Colocalization of activated PLP promoter transgene and NeuN neuronal lineage marker in neostriatum. a, b Coronal forebrain sections of rostral, middle and caudal levels of neostriatum in a P6 transgenic mouse. At low resolution $(\times 2.5$ objective $)$, neostriatum is well defined by green fluorescent EGFP+ reporter label (left). EGFP+ elements in cerebral cortex are so infrequent, dispersed and weakly fluorescent as to escape recognition. Unlabeled, irregular territories in neostriatum are fiber fascicles of internal capsule. At higher resolution $(\times 20$ objective), EGFP+ label is localized in cell bodies (upper middle). Red fluorescent NeuN+ label (lower middle) in nuclei in same sections is colocalized in EGFP+ cells in merged images (green + red fluorescence in cell bodies and their nuclei, right). c Distinct regional patterns of EGFP+ label in neostriatum and globus pallidus. At low resolution $(\times 2.5$ objective, left), EGFP+ label is located in both brain sites. At higher resolution $(\times 20$ objective), different cellular distributions occur in each site (middle left). NeuN+ label colocalizes with EGFP+ label in neostriatum (upper middle left, middle right and right), but not in globus pallidus (lower middle left, middle right and right), where EGFP+ label is mainly diffuse and not colocalized in cell bodies with NeuN+ nuclei. Dashed lines demarcate brain sites (left): neostriatum (Ns), globus pallidus (GP), cerebral cortex $(\mathrm{Cx})$, hippocampus (Hc), lateral ventricle (lv); scale bars $=400 \mu \mathrm{m}$ in left panels. White boxes indicate magnified regions (middle and right). Scale bar $=100 \mu \mathrm{m}$ in middle (a, b) and right panels (c). $\mathbf{a}, \mathbf{b}$ Scale bar $=50 \mu \mathrm{m}$ in right merged image panels. had spherical cell bodies and small diameters $<10$ (mostly 7-8) $\mu \mathrm{m}$. Group I EGFP+ cells matched settled medium-sized neostriatal neurons in conventional histology and Golgi reports [18]. Group II EGFP+ cells, which might have overlapped with group III due to neostriatal anisotrophy, matched neural progenitors (NPCs, most likely neuroblasts), migrating immature neurons and small oligodendroglial progenitor cells (OPCs) described in white matter tracts $[12,17]$. Group III, which became much more frequent with age, matched immature and mature interfascicular oligodendroglia described in white matter tracts [19]. Structural groups extended the 

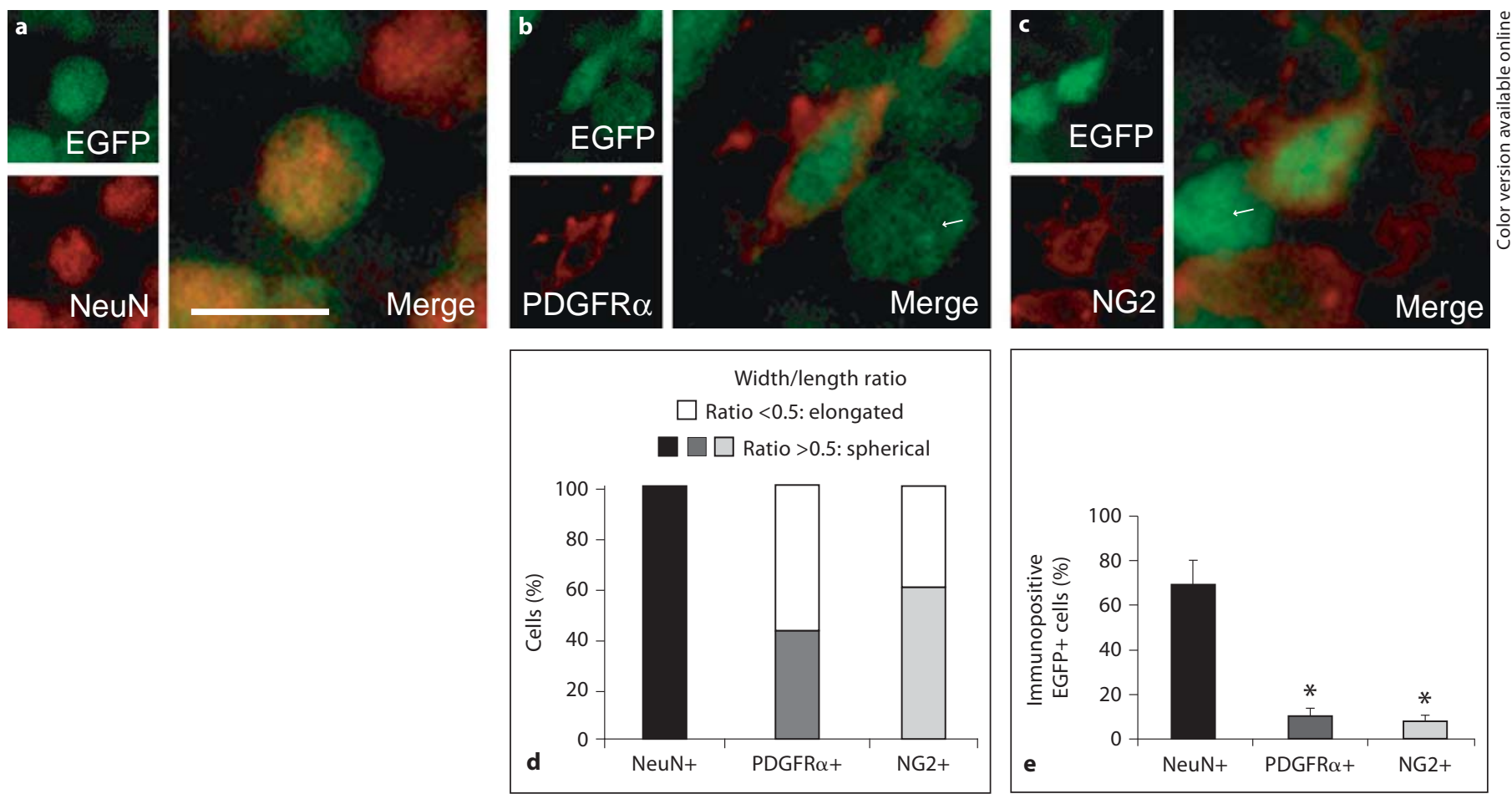

Fig. 2. $P L P$ promoter transgene activation in neuronal and oligodendroglial phenotypes of neostriatal cells during the first postnatal week (P4). a EGFP+ neuronal group. Green fluorescent EGFP+ cells have medium spherical cell bodies with red fluorescent NeuN+ label in nuclei. Green and red labels colocalize in merged images. b EGFP+ oligodendroglial (OPC) group. EGFP+ cells have small bipolar cell bodies (prominent perinuclear label) with PDGFR $\alpha+$ label in perikaryal cytoplasm. Labels colocalize in merged images. c EGFP+ oligodendroglial (OPC) group. EGFP+ cells have small bipolar and spherical cell bodies (prominent perinuclear label) with NG2+ label in perikaryal cytoplasm.
Labels colocalize in merged images. Note lack of PDGFR $\alpha$ and NG2 labels in medium spherical EGFP+ cells adjacent to doubly labeled OPCs in $\mathbf{b}$ and $\mathbf{c}$ (arrows). $\mathbf{d}$ A significantly larger proportion of EGFP+/NeuN+ cells (30 of 30 cells) displays spherical cell bodies in comparison to EGFP+/PDGFR $\alpha+$ (12 of 21 cells) or $\mathrm{EGFP}+\mathrm{NG} 2+$ (7 of 13 cells) profiles $\left(\mathrm{NeuN}+\mathrm{vs}\right.$. PDGFR $\alpha+: \chi^{2}=$ 31.22, d.f. $=1$; NeuN+ vs. NG2+: $\chi^{2}=32.18$, d.f. = 1). e A significantly larger proportion of EGFP+ cells contain NeuN (69 $\pm 11 \%)$ than PDGFR $\alpha+(10 \pm 4 \%)$ or NG2 [8 \pm 3\%; F (28.2) = 44.85; reliable NeuN vs. PDGFR $\alpha$ and NeuN vs. NG2 contrasts; ${ }^{*} \mathrm{p}_{\alpha} \mathrm{s}<$ 0.05]. a-c Scale bar for merged profiles $=10 \mu \mathrm{m}$. full depth of thick brain slices, and were not due to partial EGFP+ cell body profiles at slice faces.

Neostriatal EGFP+ cells were further delineated from $\mathrm{P} 4-\mathrm{P} 16$ by colocalization of cell lineage markers. NeuN, a pan-neuronal lineage marker, was located in frequent doubly labeled EGFP+/NeuN+ neostriatal cells in immunoreactive section faces (fig. 1). Comparable, but less densely aggregated, doubly labeled neurons were found in cerebral cortex, amygdala and hypothalamus. Among neostriatal NeuN+ neurons, 93\% were also EGFP+, a finding cross-validated with the more mature neuronal lineage marker Map2. Approximately $76 \%$ of neostriatal Map2+ neurons were also EGFP+. Differences between proportions of doubly labeled neurons obtained with these two lineage markers might reflect different age-related schedules of accumulation of the targeted antigens, variations in their preservation, and/or distinct tissue penetrances of antibodies. Such neurons were not apparent in globus pallidus, although it contained substantial numbers of EGFP+ cells (fig. 1c). At P6, EGFP+/NeuN+ neurons were group I medium spherical cells (fig. 2a). PDGFR $\alpha$ and NG2, lineage markers of early and later developmental stages of OPCs, were also located in all brain sites containing EGFP+ cells [17, 20, 21]. At P6, EGFP+/ PDGFR $\alpha+$ and EGFP+/NG2 OPCs were small bipolar and spherical cells in groups II and III. EGFP+ cells in globus pallidus were akin to groups II and III (fig. 2b, c).

Allometric associations between form, size and lineage marker expression were evident for neostriatal EGFP+ cells during the P4-P16 study period. Form was quantified as minimum somatic diameter/maximum somatic diameter. Among EGFP+ cells, spherical form had values $>0.5$ 


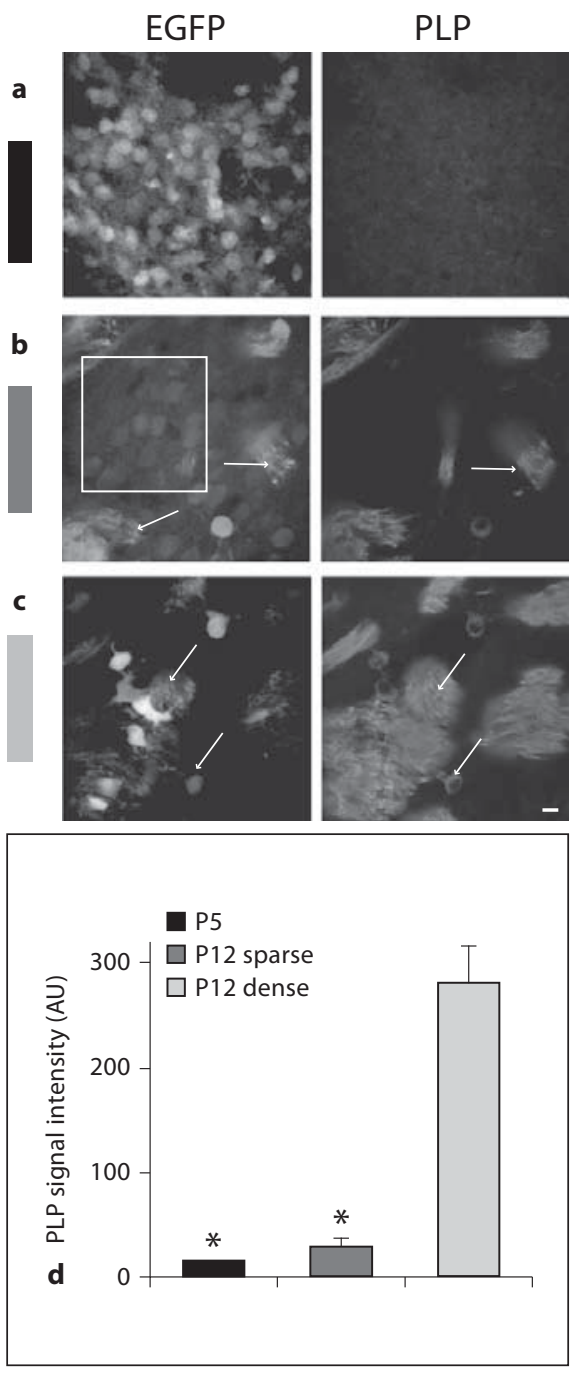

Fig. 3. Colocalization of classic PLP protein in oligodendroglial, but not neuronal, phenotype of neostriatal cells with activated PLP promoter transgene. a-c Localization of EGFP+ reporter and classic PLP protein. a Sparsely labeled EGFP+ cells contain no apparent PLP label at P5. Sparsely labeled medium spherical EGFP+ neurons also contain no apparent PLP label at P12 (white box). b, c Densely labeled small spherical EGFP+ oligodendroglia contain classic PLP label in cell bodies and proximal processes at P12 (arrows). d Histogram of average PLP label density. PLP density is significantly greater in small spherical cells with dense EGFP+ label at P12 [281 $\pm 34 \mathrm{AU}$ (arbitrary fluorescence photometry units), $\mathrm{n}=21$ ] than in medium spherical cells with sparse EGFP+ label at P5 $(15 \pm 2 \mathrm{AU}, \mathrm{n}=30)$ and P12 $(29 \pm 7$ $\mathrm{AU}, \mathrm{n}=27$; Kruskall-Wallis statistic $=44.31$; reliable post-hoc comparisons for sparse P5 vs. dense P12 EGFP+ cells and sparse P12 vs. dense P12 EGFP+ cells; $\left.{ }^{*} \mathrm{p}_{\alpha} \mathrm{s}<0.05\right)$. Scale bar for cell images $=10 \mu \mathrm{m}$. and bipolar form had values $<0.5$. When categorized in this fashion, EGFP+/NeuN+ cells were reliably associated with spherical form of medium size, while EGFP+/ PDGFR $\alpha+$ and EGFP+/NG2+ cells were reliably associated with bipolar and spherical forms of small size (fig. $2 \mathrm{~d}$ ). The proportion of small spherical cells that colocalized $\mathrm{EGFP}+/ \mathrm{PDGFR} \alpha+$ and EGFP+/NG2+ labels increased with OPC maturation, as shown by later-stage NG2 stage marker expression. The proportion of EGFP+/NeuN+ neurons in group I was reliably greater than proportions of $\mathrm{EGFP}+/ \mathrm{PDGFR} \alpha+$ and/or EGFP+/NG2+ EGFP+ OPCs in groups II and III, in accord with the expected stability of settled, postmitotic neurons unlike the extended mitotic passage of and subsequent maturation of OPCs (fig. 2e).

\section{Expression of Native PLP Proteins by Neostriatal Cells with Activated PLP Promoter}

Neostriatal EGFP+ cells with activated PLP promoter transgene expressed distinct isoforms of native PLP proteins, as shown by immunohistochemistry.

At P5, prior to the onset of myelinogenesis, neither EGFP+ nor EGFP- cells localized classic PLP/DM20 isoforms (fig. 3a; detection of classic DM20, believed to show early expression, was uncertain in neostriatum with the employed monoclonal antibody directed against PLP; color plates for fig. 3, 4, 6, and 8 are shown in the online suppl. material; www.karger.com/doi/10.1159/000330321). EGFP label did not spread into processes in EGFP+ cells (0/30 examined cells). By and after P12, densely labeled EGFP+ cells (i.e. 'bright' fluorescence indicative of high cellular accumulations of the reporter) colocalized substantial PLP immunoreactivity (fig. 3b, c). Both EGFP and PLP labels spread into processes, which extended and branched up to $25 \mu \mathrm{m}$ from origins (16/17 examined cells). Densely labeled EGFP+/PLP+ cells had small spherical characteristics of group III cells. They were putative immature and mature interfascicular oligodendroglia, as signified by their PLP signature and structural correspondence to these lineage stages. In association with myelination during and after the 4th week of postnatal development, label density in group III cells was so great that it obscured detection of group I and II cells. Distinction between sparsely and densely labeled EGFP+ cells was objectively measured by photometry, and found to be statistically reliable (fig. 3d). Unlike neostriatum, sparsely and densely labeled bipolar OPCs and more mature small spherical oligodendroglia in groups II and III were the only EGFP+ cells in globus pallidus.

Frequent, sparsely labeled group I (medium spherical) EGFP+ neostriatal neurons persisted throughout the 


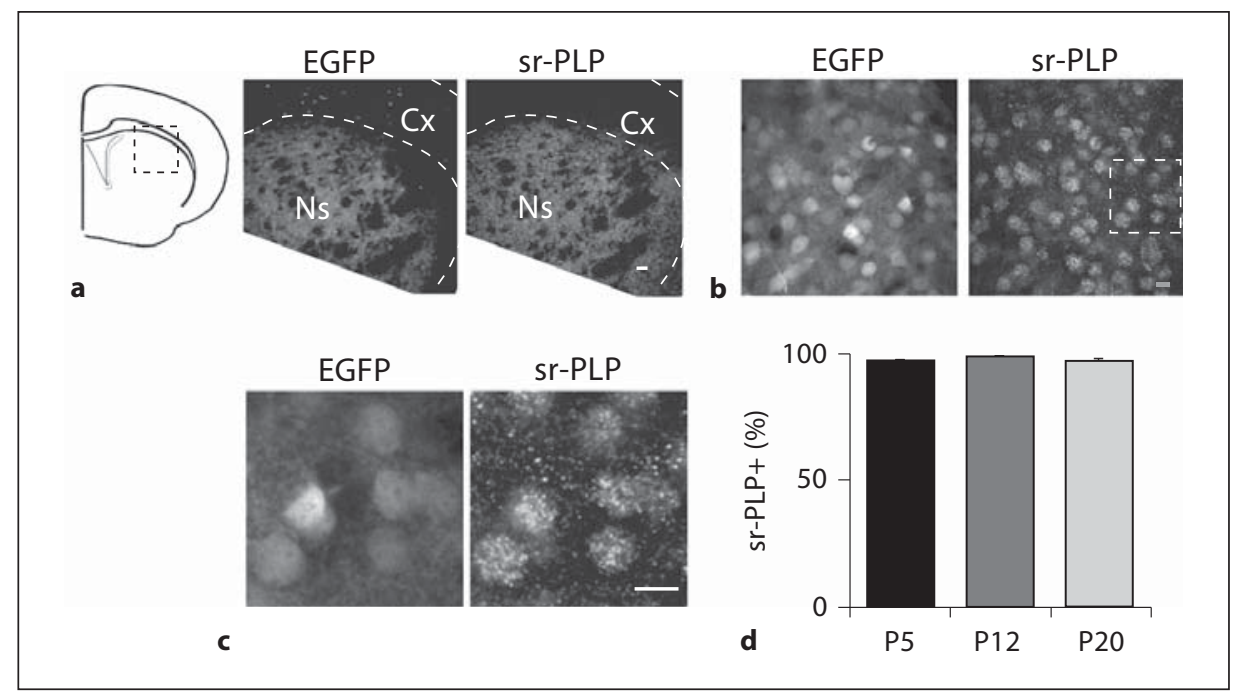

Fig. 4. Colocalization of activated PLP promoter transgene and sr-PLP protein in neostriatal neuronal phenotype. a Low resolution ( $\times 10$ objective) images of merged EGFP+ and sr-PLP+ labels at P5. Coronal section maps imaged region. b Higher resolution ( $\times 40$ objective) images of merged sparse EGFP+ and robust sr-PLP labels at P12 in a similar site. c Detail from $\mathbf{b}$ (white box) of colocalized EGFP+ and sr-PLP labels in medium spherical neurons. d Percentages of EGFP+/sr-PLP+ cells plotted as a function of age show no developmental differences with similar values at $\mathrm{P} 5(97 \pm 1 \%, \mathrm{n}=132), \mathrm{P} 12(98 \pm 1 \%, \mathrm{n}=130)$ and $\mathrm{P} 20$ $\left(98 \pm 1 \%, \mathrm{n}=110 ; \mathrm{p}_{\alpha} \mathrm{s}>0.05\right)$. Scale bars $=50 \mu \mathrm{m}(\mathbf{a})$ and $10 \mu \mathrm{m}$ (b, c). study period. EGFP label did not spread into processes. In accord with a putative neuronal lineage, they did not express classic PLP (fig. 3b).

Both densely and sparsely labeled (groups I-III) neostriatal EGFP+ cells expressed sr-PLP/sr-DM20 isoforms (collectively termed sr-PLP cells; either or both sr isoforms might have been detected by the employed polyclonal sr-PLP antibodies). Regardless of intracellular accumulations of EGFP, EGFP+/sr-PLP+ cells were always found to be the most frequent cells in neostriatum from P4-P20 (fig. 4). The high degree of overlap between sparsely labeled EGFP+ cells and sr-PLP+ cells was stable across age, consistent with the persistent numerical predominance of sparsely labeled group I EGFP+ neostriatal neurons (contrast fig. $2 \mathrm{~d}$ and $4 \mathrm{~d}$ ). This combination of double labeling, and consistently high frequencies of doubly labeled cells throughout early postnatal development, demonstrated that sparsely labeled group I EGFP+ neurons in neostriatum expressed sr-PLP in conjunction with activated $P L P$ promoter.

\section{Physiological Characteristics of Neostriatal Cells with} Activated PLP Promoter

The different structural characteristics of neostriatal cells with activated PLP promoter provided a valuable opportunity to target patch clamp recording studies for de- termination of viability and corresponding functional characteristics. We focused on sparsely labeled neostriatal EGFP+ cells, present from P4-P20 in transgenic mice, in order to compare the electrophysiological properties of nascent morphological groups.

During early postnatal development (P4-P7), the majority of sparsely labeled neostriatal EGFP+ cells exhibited high resistance membranes expected of immature cells, including neurons $(3.10 \pm 0.33 \mathrm{G} \Omega, \mathrm{n}=40)$, but their other functional characteristics displayed categorical differences. Three functional classes (termed for ease of distinction from the three structural groups) of neostriatal EGFP+ cells were recognized based on their excitability and expression of voltage-gated $\mathrm{K}^{+}$currents (fig. 5a). Class I cells had moderate transient A-type ( $\left.\mathrm{I}_{\mathrm{KA}}\right)$ currents, sustained delayed rectifier $\mathrm{K}^{+}$currents $\left(\mathrm{I}_{\mathrm{KDR}}\right)$, moderate-to-large $\mathrm{Na}^{+}$currents $\left(\mathrm{I}_{\mathrm{Na}}\right)$ and fired APs upon depolarization, which identified them as neurons [22]. Class I was subdivided into neurons firing single APs versus multiple APs in response to positive current injection. Class II cells did not fire regenerative APs, lacked a prominent $\mathrm{I}_{\mathrm{KA}}$, had a small $\mathrm{I}_{\mathrm{KDR}}$, and possessed small $\mathrm{I}_{\mathrm{Na}}$. Class III cells did not fire APs, exhibited large $\mathrm{I}_{\mathrm{KA}}$ and sustained $\mathrm{I}_{\mathrm{KDR}}$, and had small $\mathrm{I}_{\mathrm{Na}}$.

Electrophysiological properties of these functional classes are summarized in table 1 . Consistent with the 
Fig. 5. Physiological characteristics of neostriatal neuronal and oligodendroglial phenotypes with $P L P$ promoter transgene activation during the first postnatal week (P4-P7). a Current clamp (top traces) and voltage clamp (bottom traces) records from EGFP+ cells show three functional classes. Class I cells are a mature neuronal phenotype, subdivided into cells that fire single and multiple APs. Class II cells display physiological properties consistent with earliest stages of neuronal development. Class III cells exhibit physiological hallmarks of oligodendrocyte precursors. b-d Physiological maturation of class I EGFP+ neurons. Multiple AP neurons have a more mature functional profile than single AP neurons with greater AP slope $(t=3.06$, d.f. $=23)$ and reduced AP half-width $(t=3.53$, d.f. $=23$; b $)$, greater voltage-gated $\mathrm{Na}^{+}$currents $(\mathrm{t}=2.63$, d.f. $=$ 23 ; c), and greater voltage-gated $\mathrm{K}^{+}$currents $\left(U=27 ;{ }^{*} \mathrm{p}_{\alpha} \mathrm{s}<0.05 ; \mathbf{d}\right)$.

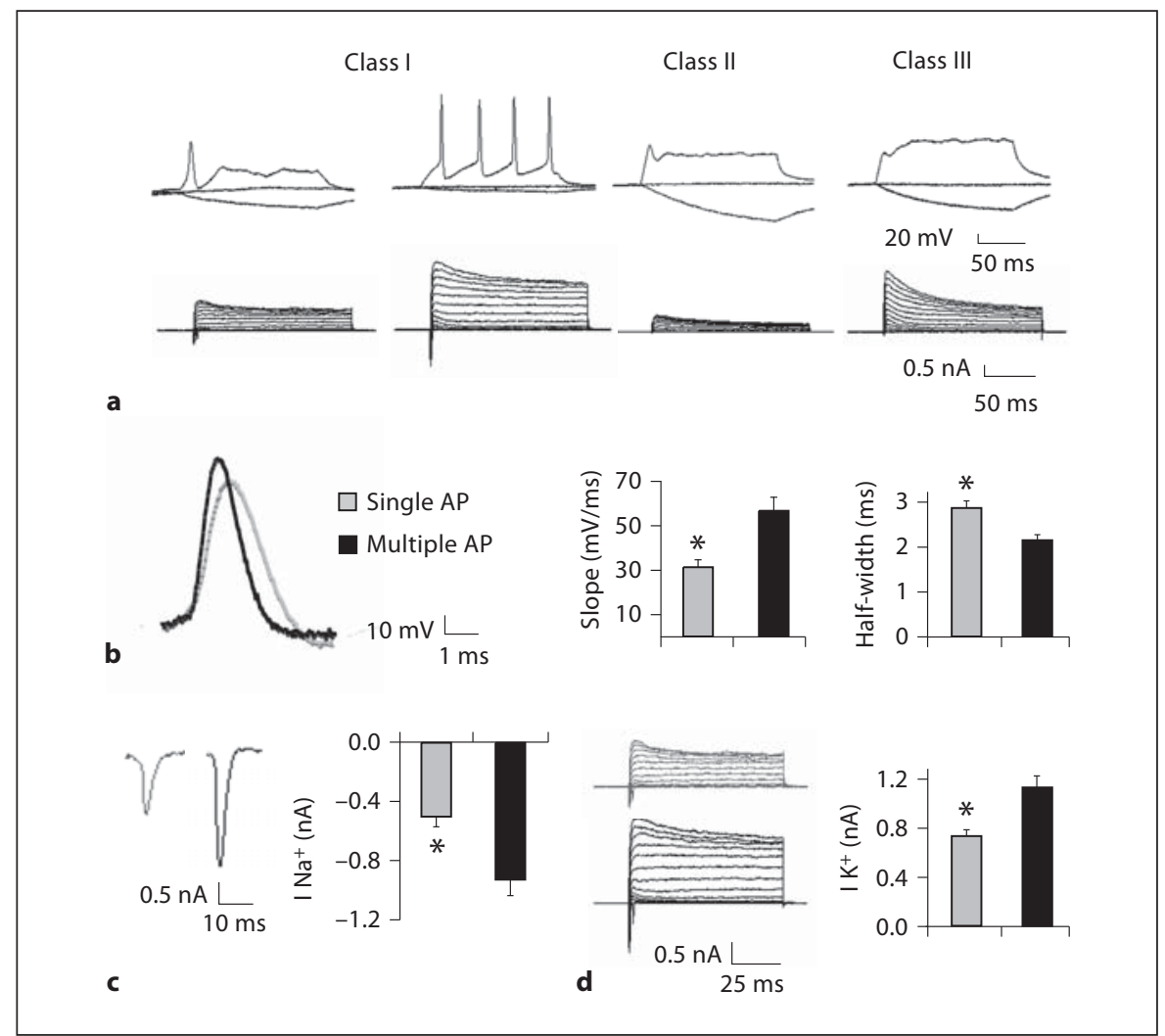

Table 1. Physiological characteristics of neostriatal cells with activated PLP promoter transgene

\begin{tabular}{|c|c|c|c|c|}
\hline \multirow[t]{2}{*}{ Excitability } & \multirow{2}{*}{$\begin{array}{l}\text { Class III } \\
\text { OPC } \\
\text { no/graded spike }\end{array}$} & \multirow{2}{*}{$\begin{array}{l}\text { Class II } \\
\text { NPC/migrating neuron } \\
\text { no/graded spike }\end{array}$} & \multicolumn{2}{|l|}{$\begin{array}{l}\text { Class I } \\
\text { neuron }\end{array}$} \\
\hline & & & single AP & multiple AP \\
\hline $\mathrm{RMP}, \mathrm{mV}$ & $-72 \pm 7.2$ & $-60 \pm 4.5$ & $-61 \pm 4.1$ & $-65 \pm 2.8$ \\
\hline $\mathrm{R}_{\mathrm{In}}, \mathrm{G} \Omega$ & $1.6 \pm 0.2$ & $5.3 \pm 1.2$ & $3 \pm 0.6$ & $3 \pm 0.3$ \\
\hline Transient - $\mathrm{I}_{\mathrm{KA}}, \mathrm{pA}$ & $1,271 \pm 105$ & $333 \pm 26$ & $440 \pm 32$ & $570 \pm 38$ \\
\hline Steady-state $\mathrm{I}_{\mathrm{KDR}}, \mathrm{pA}$ & $534 \pm 79$ & $303 \pm 39$ & $404 \pm 33$ & $520 \pm 38$ \\
\hline Ratio $\mathrm{I}_{\mathrm{KA}} / \mathrm{I}_{\mathrm{KDR}}$ & $2.6 \pm 0.3^{*}$ & $1.2 \pm 0.1$ & $1.1 \pm 0.0$ & $1.1 \pm 0.0$ \\
\hline $\mathrm{Max}_{\mathrm{Na}}, \mathrm{pA}$ & $-209 \pm 51$ & $-131 \pm 35$ & $-498 \pm 74$ & $-924 \pm 112$ \\
\hline
\end{tabular}

$\mathrm{RMP}=$ Resting membrane potentials. ${ }^{*} \mathrm{p}_{\alpha}<0.05$, pairwise contrasts between classes III vs. II, I-single AP and I-multiple AP.

predominance of EGFP+/NeuN+ neurons, class I cells capable of firing APs formed the majority of the targeted sample ( 25 of 40 recorded cells). Among class I cells, AP waveforms were sharper in the multiple AP than the single AP subdivision, which reflected a range of maturational states (fig. 5b). For class I neurons in the multiple AP subdivision, AP slope was reliably increased while AP half-width was reliably reduced, indicative of enhanced AP kinetics (fig. 5b). AP rise and decay times were significantly reduced in these cells, while peak $\mathrm{I}_{\mathrm{Na}}$ and $\mathrm{I}_{\mathrm{KDR}}$ were reliably increased (fig. $5 \mathrm{c}$, d). Class II cells ( 8 of 40 recorded cells) had the low degree of excitability, apparent lack of $I_{K A}$, and moderate $I_{K D R}$ typical of early NPCs or pre-settlement stages of development for neurons [23]. 


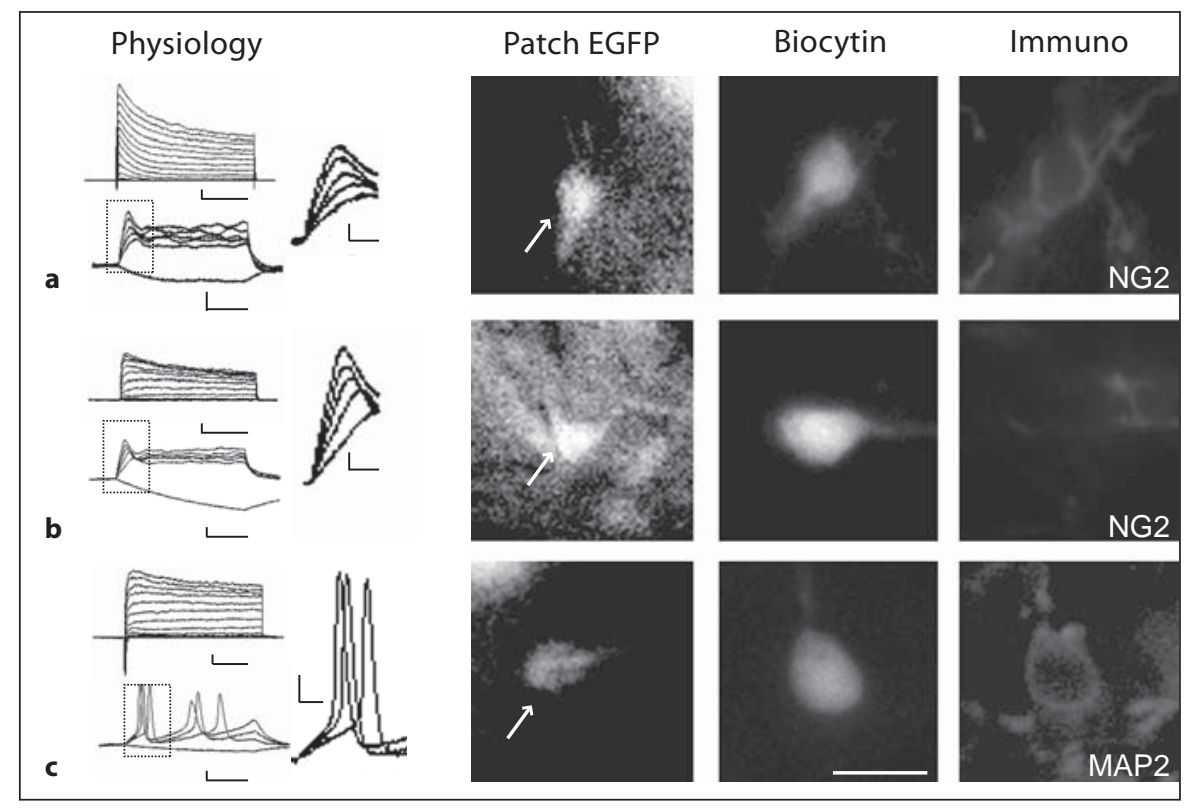

Fig. 6. Correlation of morphological groups and electrophysiological classes of neostriatal cells with PLP promoter transgene activation during the first postnatal week (P4-P7). a-c Examples of voltage clamp (upper traces) and current clamp (lower traces) records (physiology column; insets show boxed regions on an expanded time base) from EGFP+ cells (arrows, patch EGFP column) for small bipolar cells (a, b) and medium spherical cells (c). Putative OPCs (a) and putative NPCs and migrating neurons (b)

Class II cells were distinguished from class III OPCs by absence of a pronounced $\mathrm{I}_{\mathrm{KA}}$, which was reflected in a transient/steady-state $\mathrm{I}_{\mathrm{K}}$ ratio of $\sim 1$. Class III cells ( 7 of 40 recorded cells) had the prominent $\mathrm{I}_{\mathrm{KA}}$ and $\mathrm{I}_{\mathrm{KDR}}$, and lack of a regenerative AP typical of OPCs $[17,24]$. The large amplitude of $\mathrm{I}_{\mathrm{KA}}$ in putative OPCs increased the ratio of $\mathrm{I}_{\mathrm{KA}} / \mathrm{I}_{\mathrm{KDR}}$ (transient/steady-state $\mathrm{I}_{\mathrm{K}}$ ), not apparent in other classes of EGFP+ cells.

In all cases, class I cells were selected as representatives of medium spherical EGFP+ (structural group I) neostriatal cells. Double labeling revealed positive examples of class I cells that were EGFP+/Map2+ neurons, a cell lineage and developmental status consistent with their substantial $\mathrm{Na}^{+}$current and regenerative APs (fig. 6c). Also in all cases, class II and III cells were selected as representatives of small bipolar EGFP+ (structural group II) neostriatal cells. Double labeling revealed no examples of class II EGFP+ neostriatal cells that expressed NG2, a negative outcome suggestive but not conclusive of their putative neuronal lineage (fig. 6b). These cells also escaped detection with neuronal lineage markers NeuN and Map2, probably due to their very early developmental generate graded spikes, while putative neurons (c) display all-ornothing APs. Filled with biocytin (biocytin column), these cells are then labeled for OPC and neuronal lineage markers (immuno column). Class III oligodendroglial cell is NG2+ (P7), class II early neuron is NG2- (P4), and class I neuron is Map2+ (P5; a multiple AP cell). Scale bars for physiology traces: voltage clamp $=200$ $\mathrm{pA} / 50 \mathrm{~ms}$, current clamp $=20 \mathrm{mV} / 50 \mathrm{~ms}$, inset traces $=20 \mathrm{mV} / 10$ $\mathrm{ms}$. Scale bar for cell images $=10 \mu \mathrm{m}$.

status (fig. 2d); however, they regularly generated a graded low amplitude spike consistent with an early stage of neuronal differentiation (fig. 6b). Double labeling revealed positive examples of class III cells that were EGFP+/ NG2+ OPCs (fig. 6a). In some cases, depolarization of putative OPCs produced a small spike whose amplitude increased in a graded fashion with increasing current injection (fig. 6a inset); nevertheless, kinetics, amplitude and lack of regenerative response distinguished these spikes from neuronal APs (fig. 6a, c).

\section{Ontogeny of Neurotransmission in Neostriatal \\ Neurons with Activated PLP Promoter}

The increasing excitability of neostriatal EGFP+ neurons during early postnatal development was due, at least in part, to progressive maturation of synaptic afferents and/or receptive substrates. The appearance of sEPSCs was contrasted between early and later postnatal periods in sparsely labeled EGFP+ neostriatal neurons identified by their morphological properties, pattern of membrane currents, and excitability (group I/class I; fig. 7). During the first postnatal week (P4-P5), few EGFP+ neurons had 

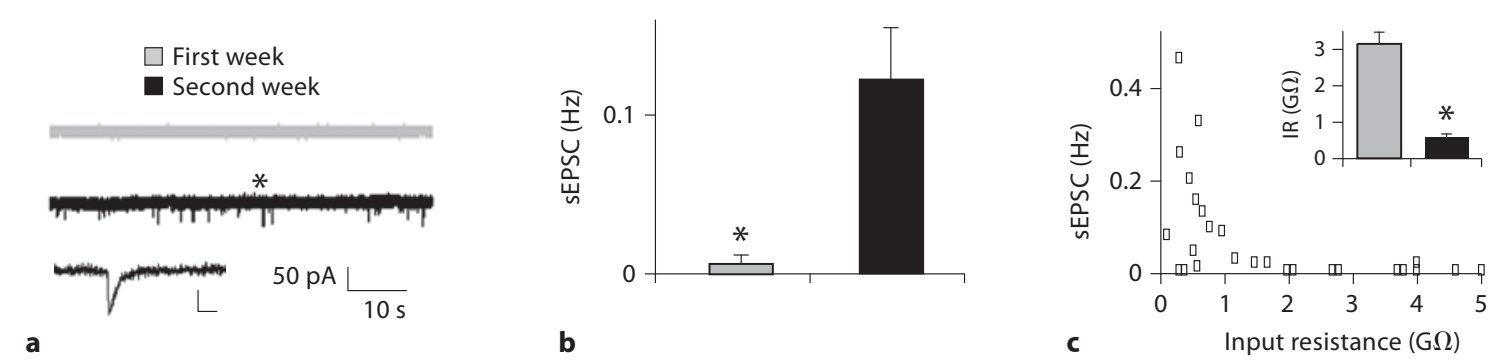

Fig. 7. Acquisition of synaptic connectivity by the neuronal phenotype of neostriatal cells with PLP promoter transgene activation. a Sample sEPSC records from EGFP+ neurons during 1st (grey trace, P4-P7) and 2nd (black trace, P8-P14) postnatal weeks. Lower trace is an example of a spontaneous synaptic current on an expanded time base (asterisk denotes location of inset). b Histogram of average frequencies for sEPSC records during 1st and 2nd weeks. sEPSC frequency is reliably greater in EGFP+ neu- rons in 2nd postnatal week ( 1 st week $=0.003 \pm 0.002 \mathrm{~Hz}, \mathrm{n}=14$; 2nd week $=0.13 \pm 0.04 \mathrm{~Hz}, \mathrm{n}=14 ; \mathrm{U}=20$ ). c sEPSC frequency as a function of input resistance. Input resistance is reliably and negatively correlated with sEPSC frequency $(r=-0.65)$. In inset, average input resistance for EGFP+ neurons decreases significantly with age (1st week $=3.14 \pm 0.31 \mathrm{G} \Omega, \mathrm{n}=14 ; 2$ nd week $=0.59 \pm$ $0.07 \mathrm{G} \Omega, \mathrm{n}=14 ; \mathrm{t}=8.03$, d.f. $\left.=26,{ }^{*} \mathrm{p}_{\alpha} \mathrm{s}<0.05\right)$. a Scale bars for inset $=50 \mathrm{pA} / 10 \mathrm{~ms}$. spontaneous membrane currents (2/14 recorded cells; fig. 7a), and when present, these currents had small amplitudes ( 5pA). During the second postnatal week (P9P15), most EGFP+ neurons had numerous spontaneous currents (12/14 recorded cells; fig. 7a), and these currents had increased amplitudes (range $=5-50 \mathrm{pA}$ ). In these more mature neurons, current frequency was attenuated by the AMPA-type glutamate receptor antagonist CNQX (pre-CNQX: $13 \pm 3 \mathrm{~Hz}, \mathrm{n}=3$; post-CNQX: $2 \pm 2 \mathrm{~Hz}$, $\mathrm{n}=3$ ), and thus represented glutamatergic sEPSCs. The average frequency of sEPCSs increased between the first and second postnatal weeks (fig. 7b). EGFP+ neurons also had a reliable decrease in input resistance during this period (fig. 7c inset), while input resistance was always negatively correlated with sEPSC frequency (fig. 7c). Progressive, parallel decreases in input resistance and increases in synaptic input were consistent with dendritic growth and/or spine generation.

\section{Identification of Type(s) of Neostriatal Neurons with Activated PLP Promoter}

The collective structural and functional characteristics of EGFP+ neostriatal neurons with activated PLP promoter identified them as medium spiny neurons. Medium spiny cells (with two minor variants that both emit projection and local axonal collaterals) constitute approximately $95 \%$ of neostriatal neurons $[18,25]$, a value that closely approximated the prevalence of EGFP+/ $\mathrm{NeuN}+$ neostriatal neurons observed during and after the first postnatal week in transgenic mice. Between P4P20, frequent medium EGFP+ neurons and infrequent large EGFP- cells, likely in the latter case to have represented large 'aspiny' neurons that usually emit only local axons, were found in neostriatum. This observation indicated that PLP promoter activation was widespread but restricted to particular type(s) of neostriatal neurons. This categorization also afforded a valuable opportunity to target patch clamp recordings to these two contrasting types of cells for comparisons of their development in the early postnatal period.

Medium spherical EGFP+ neostriatal neurons (group I/class I) displayed a striking electrophysiological uniformity. They showed little or no spontaneous AP generation at normal resting potentials (fig. 8a) and significant spike accommodation during current injection (fig. 8b). Their mean input resistance $(642 \pm 0.09 \mathrm{M} \Omega$ ) was comparable to values obtained previously for immature medium spiny neurons $[26,27]$ and was significantly greater than the value obtained from large EGFP- cells (380 \pm $1.49 \mathrm{M} \Omega ; \mathrm{U}=11.5, \mathrm{p}<0.05)$. Similar to an earlier report [22], EGFP+ neurons had a pronounced inward rectification of the I-V relationship during hyperpolarizing and depolarizing current injection, responses that were absent in large EGFP- cells (fig. 8c). EGFP+ neurons also had a positive expression of DARPP-32, a dopamine receptor-associated protein sometimes used to identify putative medium spiny neurons in intact forebrain (fig. 8d) [28]. When recovered after intracellular biocytin injec- 


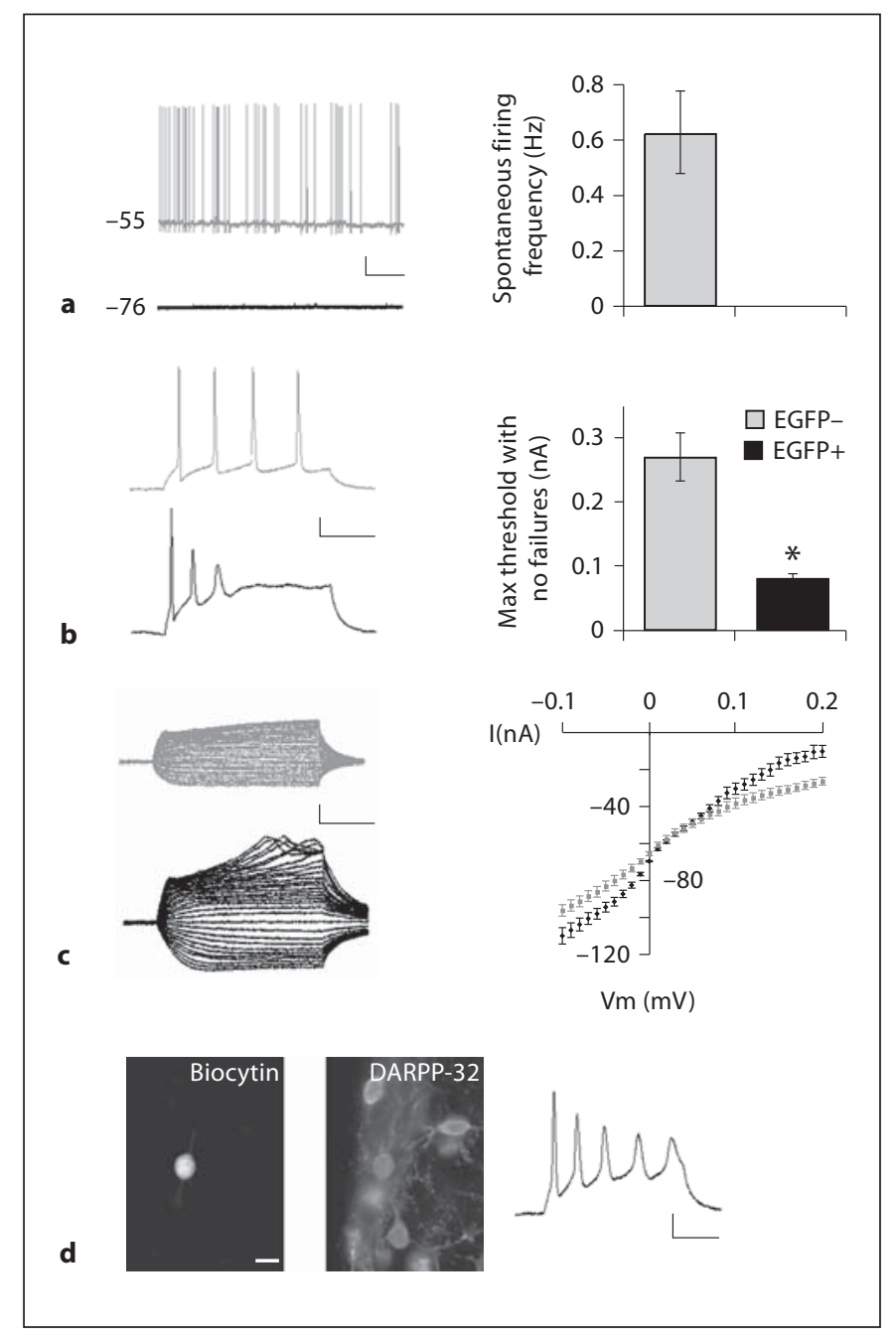

Fig. 8. Physiological characteristics of medium spiny neostriatal neurons with PLP promoter transgene activation (P10-P16). a Infrequent or absent spontaneous APs in EGFP+ neurons. Examples from EGFP- (grey trace) and EGFP+ (black trace) neurons [left; numerals $=$ resting membrane potentials $(\mathrm{mV})$; scale bar $=20$ $\mathrm{mV} / 5 \mathrm{~s}$. Average spontaneous firing frequency in EGFP- $(0.63 \pm$ $0.15 \mathrm{~Hz}, \mathrm{n}=9)$ and EGFP+ neurons $(0 \pm 0 \mathrm{~Hz}, \mathrm{n}=10$; right $)$. b Pronounced AP accommodation in EGFP+ neurons. Examples of APs evoked by injection of $0.12 \mathrm{nA}$ (left; scale bar $=20 \mathrm{mV} / 50$ $\mathrm{ms}$ ). Average threshold (no AP failure) is significantly lower in EGFP+ neurons (right; EGFP- $=0.27 \pm 0.04 \mathrm{nA}, \mathrm{n}=9$, vs. $\left.\mathrm{EGFP}+=0.08 \pm 0.01 \mathrm{nA}, \mathrm{n}=9 ; \mathrm{U}=8.5 ;{ }^{*} \mathrm{p}_{\alpha}<0.05\right)$. $\mathrm{c}$ Pronounced rectification of $\mathrm{I}-\mathrm{V}$ response in $\mathrm{EGFP}+$ neurons. Examples of voltage responses from EGFP- (grey) and EGFP+ (black) neurons in presence of tetrodotoxin (left; scale bars $=20 \mathrm{mV} / 50 \mathrm{~ms}$ ). Average I-V curves from EGFP+ $(n=10)$ and EGFP- neurons $(n=9$; right $)$. d Postrecording DARPP-32 localization in an EGFP+ neuron (P7). Fluorescent image of biocytin loaded into EGFP+ cell during patch clamp recording (left) and immunolabel of the same site with anti-DARPP-32 (middle). This cell shows significant AP accommodation, a usual feature of EGFP+ neostriatal neurons (right). Scale bar for cell images $=10 \mu \mathrm{m}$; for physiology records $=20 \mathrm{mV} / 50 \mathrm{~ms}$. tions, all EGFP+ neurons had medium-sized and spherical cell bodies of 10 - to $15-\mu \mathrm{m}$ diameter (fig. 9a). Their dendrites (4-7 primary dendrites/neuron) had thin shafts and numerous varicosities, which decreased with age. Their distal dendritic segments, usually $>3$ rd branch order, emitted characteristic spines, which became more frequent and uniformly shaped with age (fig. 9). Thus, sparsely labeled EGFP+ neurons were directly identified as developing medium spiny neostriatal neurons consistent with previous functional and structural descriptions obtained from young rats $[26,27]$.

Large EGFP- cells were also neurons, as shown by spontaneous generation of APs at normal resting potentials (fig. 8a). In contrast to EGFP+ neurons, they did not exhibit spike accommodation during current injection (fig. 8b). Their post-AP AHPs were reliably prolonged when compared to EGFP+ neurons $(21.6 \pm 3.89$ vs. 2.48 $\pm 0.54 \mathrm{~ms}$ ). These properties resembled those found for aspiny neurons of comparable size in young rats [29]. There was also evidence of additional diversity among EGFP- neurons, with one example ( $1 / 20$ cells) of a fastspiking cell with a high firing frequency $(114.3 \mathrm{~Hz})$ and brief AP/AHP kinetics [30]. When recovered after intracellular biocytin injections, all EGFP- neurons had largesized multipolar cell bodies of 20- to $30-\mu \mathrm{m}$ maximum diameter, and were reliably bigger than EGFP+ neurons obtained at the same age. Their proximal dendritic segments tended to be thick, dendritic varicosities were uncommon, and dendritic spines were rarely observed regardless of age.

\section{Discussion}

Novel evidence obtained in this investigation demonstrates beyond a reasonable doubt that PLP gene expression occurs in both neuronal and oligodendroglial phenotypes in the developing neostriatum of mice that bear the PLP promoter transgene. This conclusion is based on three fundamental observations. First, an EGFP reporter of PLP promoter activation in transgenic mice is certainly localized in two distinct populations of cells, which exhibit collective, emergent differences of morphological and physiological characteristics in accord with the neuronal and oligodendroglial phenotypes of neostriatal cells found during early postnatal development in both mutant and wild-type mice $[17,24,31,32]$. The present assessment of characteristics that comprise the phenotypes is not exhaustive, but it is sufficient to demonstrate the age-related divergence of viable neuronal and oligodendroglial cells 
Fig. 9. Identified medium spiny neostriatal neurons with PLP promoter transgene activation (P6-P14). a Camera lucida drawings of representative EGFP+ and EGFPneurons filled with biocytin during patch clamp recording. EGFP+ cell (P10) is an immature medium spiny neuron with thin primary dendrites, numerous varicosities (grey arrows) and distal dendrites decorated with spines (black arrows). EGFP-cell (P16) is an immature large aspiny neuron with thick primary dendrites, infrequent varicosities and few dendritic spines. Somatic axes of medium spiny EGFP+ neurons (long axis $=12 \pm 1 \mu \mathrm{m}$, short axis = $8 \pm 1 \mu \mathrm{m}, \mathrm{n}=9$ ) are reliably less than in large aspiny EGFP- neurons (long axis = $26 \pm 2 \mu \mathrm{m}$, short axis $=11 \pm 1 \mu \mathrm{m}, \mathrm{n}=$ 14 ; long axis: $U=0.5$; short axis: $U=12.5$; $\mathrm{p}_{\alpha} \mathrm{s}<0.05$; scale bar $\left.=50 \mu \mathrm{m}\right)$. Sample records from these cells show characteristic firing responses of EGFP+ and EGFPneurons. Note pronounced AP accommodation by EGFP+ cell, and extended AHP duration by EGFP- cell (dashed lines). b Photomicrographs of representative $\mathrm{EGFP}+$ and EGFP- neurons. Lower images are enlargements of boxed areas. EGFP+ neurons have thin spiny dendrites $\left(^{*}\right)$, while EGFP- neurons have thick, smooth aspiny dendrites. Scale bars for cell images $=10 \mu \mathrm{m}$.

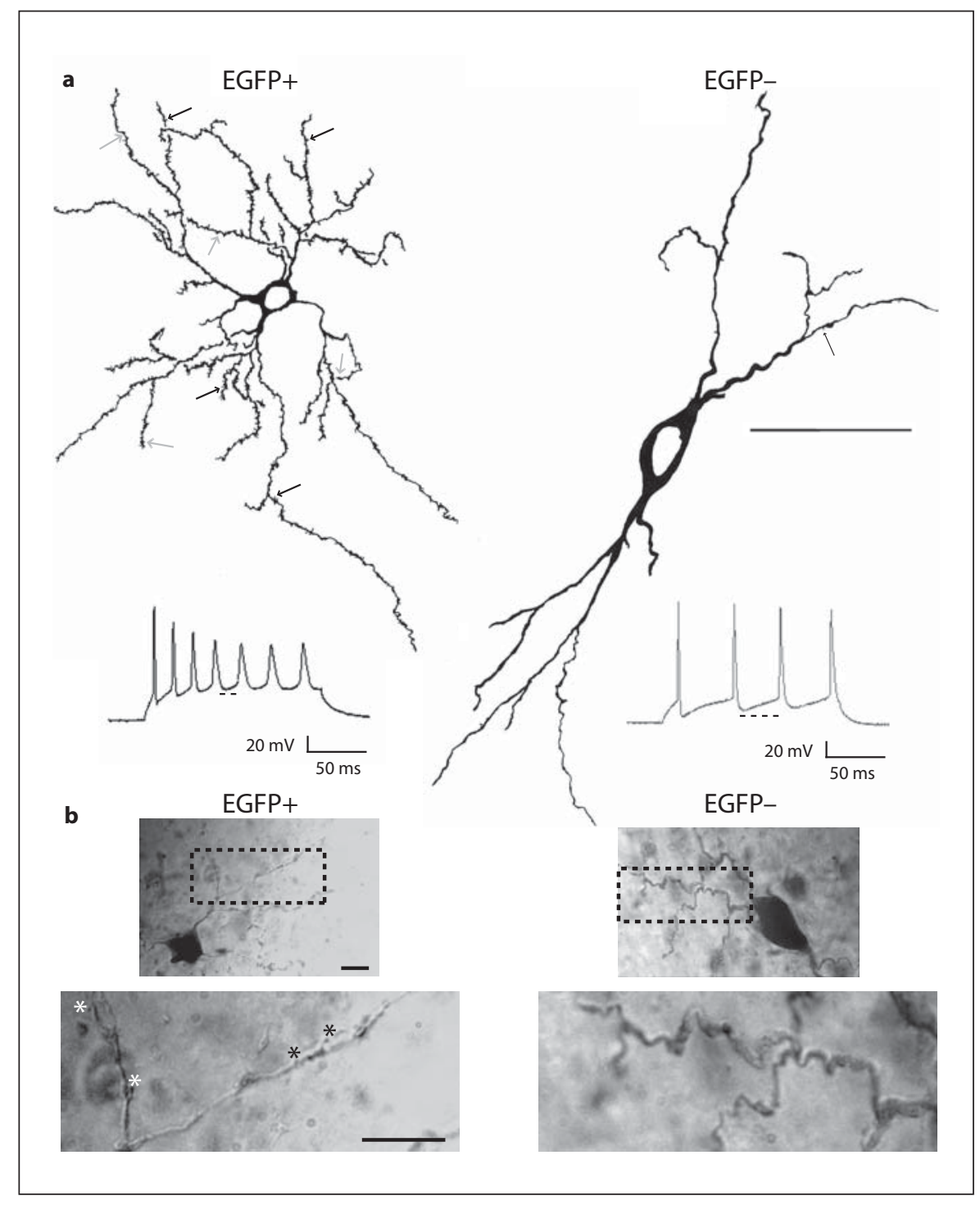

that activate the PLP promoter transgene, and to resolve, particularly by electrophysiological means, several key morphological characteristics shared by these two phenotypes during their early, primitive stages of development. Second, the EGFP reporter of PLP promoter activation in transgenic mice is appropriately positioned to serve as a regulator of PLP gene expression. It is colocalized with native PLP proteins in both neuronal and oligodendroglial phenotypes; however, only soma-restricted(sr) PLP protein isoforms are localized in the neuronal phenotype, while classic and sr-PLP isoforms are localized in the oligodendroglial phenotype $[8,10]$. Third, the EGFP reporter of PLP promoter activation in transgenic mice is placed to regulate $P L P$ gene expression in only one neuronal phe- notype among the several that constitute neostriatum. It is localized in medium spiny neurons, but not large aspiny neurons [26, 27]. Taken singly or together, these positive results necessarily lead to rejection of the hypothesis that oligodendroglia, but not neurons, exhibit PLP gene promoter activation in neostriatum of mice that bear the PLP promoter transgene.

The new observations are a modest, incremental advance in the elucidation of PLP gene expression in the oligodendroglial phenotype. As expected, morphological and electrophysiological patterns of development for the oligodendroglial phenotype in fiber fascicles of internal capsule that pass through neostriatum closely resemble patterns obtained in corpus callosum and subcortical 
white matter [17]. The former is rarely studied, while the latter is the subject of many prior investigations. Of greater significance, immature and mature oligodendroglia in transgenic and wild-type mice contain the molecular machinery required for the production of PLP proteins, as indicated by colocalizations of interrelated mRNA, promoter and proteins [10,33-35]. With age, the oligodendroglial phenotype shifts from a sparse to a dense pattern of intracellular EGFP+ labeling, an upregulation likely to reflect a high level of activation (and consequent reporter accumulation) of native and transgene PLP promoter elements triggered only within the oligodendroglial phenotype by events within the context of normal development. This shift coincides with previously described up-regulations of PLP mRNA and classic PLP levels that accompany myelinogenesis. The sparse pattern of intracellular EGFP+ label precedes the shift, and may reflect a low, steady-state activation of native and transgene promoter elements that accompanies expression of $\mathrm{sr}$ PLP, but not classic PLP, during early development (OPCs) and throughout myelinogenesis (immature and mature interfascicular oligodendroglia) $[10,12]$.

The new observations are a significant advance in the elucidation of PLP gene expression in the neuronal phenotype. Due to technical limitations, previous in situ hybridization and immunohistochemical studies do not recount localization of substantial levels of mRNA or protein markers of $P L P$ gene expression in neostriatal neurons in wild-type mice. However, the development of the neostriatal neuronal phenotype with PLP promoter transgene activation resembles, and likely precedes, the sparse label pattern observed in the oligodendroglial phenotype. This pattern of sparse EGFP+ label is maintained throughout early postnatal development and the establishment of synaptic connectivity. It may reflect a low, steady-state activation of native and transgene promoter elements that accompanies expression of sr-PLP, but not classic PLP. It is not upregulated during myelinogenesis, which is not an autonomous function of the neuronal phenotype. To a reasonable certainty, colocalization of EGFP and sr-PLP in neostriatal neurons of transgenic mice is in accord with marginal observations of sparsely labeled neostriatal neurons that localize sr-PLP in wildtype mice [pers. obs., 10]. Taken together, these results suggest that $P L P$ gene expression, insofar as it pertains to production of sr-PLP, is a shared characteristic of neuronal and oligodendroglial phenotypes in neostriatum in mice, perhaps derived from a common precursor within their respective cell lineages.
PLP promoter transgene activation in a neuronal phenotype in neostriatum is consistent with and extends previous reports of EGFP reporter localization in brainstem and hypothalamic neurons [2, 11]. These earlier studies, which do recognize the colocalization relationship between PLP promoter transgene and sr-PLP expression in neuronal and oligodendroglial phenotypes, do not localize these markers in neostriatum. They provide no systematic account of emergent morphological and electrophysiological characteristics of neurons with PLP promoter transgene activation as they progress through distinct developmental stages, important features of the present study. A recent report demonstrates conditional activation of a PLP promoter transgene in forebrain neurons [35]. Focused on cerebral cortex, it also shows derivation of activated neostriatal neurons from a pre-existent neuronal lineage, similar to our findings of immature EGFP+ NPCs and neurons, and consistent with infrequent but persistent postnatal neurogenesis of mouse neostriatum. In neostriatal neurons, tamoxifen triggered, over a permissive background of native development, a late, rapid onset of low, steady-state transgene activation accompanied by accumulation of PLP mRNA. We show that the native course of development is adequate to trigger and maintain an early, gradual onset of low, steadystate transgene activation in neostriatal neurons.

There is probable cause to suspect that PLP promoter transgene activation leads to upregulation of PLP proteins in mutant vs. wild-type mice, an issue complicated by inclusion of lineage-specific enhancers in constructs used to generate these transgenes [36]. In young neostriatal neurons, sr-PLP is clearly shown in transgenic mice by fluorescence immunohistochemistry, but less certainly shown in wild-type mice by peroxidase immunohistochemistry, a more efficient detection method. Enhanced levels of PLP gene expression in transgenic mice do not appear to impair the viability of neuronal or oligodendroglial phenotypes, which resemble intact neostriatum in wild-type rodents studied at similar ages [26, 27, 29]. Such negative functional outcomes, drawn from indirect comparisons of transgenic and wild-type mice, are suggestive but not conclusive; however, they weigh against proposals that augmented levels of PLP gene products, particularly classic PLP isoforms, reduce cell survival via programmed cell death $[6,8]$.

The new evidence for PLP promoter transgene activation and sr-PLP expression in a single neuronal phenotype in developing neostriatum, medium spiny neurons, has several significant implications: (1) It lends credibility to recognition of sparse sr-PLP accumulation in this 
largest subpopulation of mature neostriatal neurons, which indicates that PLP gene expression has both maintenance and developmental roles in restricted neuronal phenotypes. Within neostriatum, contrasts between medium spiny neurons (with sr-PLP expression) and large aspiny neurons (without sr-PLP expression) may help to resolve non-canonical roles of PLP isoforms in endocytotic trafficking/recycling, ion exchange, and/or process outgrowth [7]. (2) Medium spiny neostriatal neurons synthesize $\gamma$-aminobutyric acid as their signature inhibitory neurotransmitter [37], a characteristic not associated with neocortical, brainstem and hypothalamic neurons previously shown to have PLP gene expression $[10,11,15$, 30]. This suggests that $P L P$ gene expression is unrestricted in regard to excitatory vs. inhibitory neurotransmitter signatures. (3) Medium spiny neostriatal neurons emit myelinated projection and unmyelinated local collateral axons $[38,39]$. Myelination of projection axons through interactions with interfascicular oligodendroglia is unlikely to be a direct consequence of their autonomous PLP gene expression, initiated before the onset of myelinogenesis and with different outcomes in projection vs. local axonal domains.

The sr-PLP products of the PLP gene arise from alternative splicing of mouse exon 1.1 [8]. This exon is not conserved in humans, but two novel exons found within intron 1 of the human PLP1 gene [40] may have similar functions to those performed by the mouse sr-PLP tran- script. Their alternative splicing generates four novel mRNAs. Three show neuronal expression in human cerebral cortex, cerebellum and neostriatum, and one leads to a neuronal PLP protein product. These human PLP transcripts and proteins show patterns of expression that resemble mouse sr-PLP $[10,11]$, and neostriatal expression of PLP gene products may be a conserved feature of mammalian evolution. Neurons may also serve as a pathologic locus, and perhaps a primary pathologic cause, in human neurological disorders associated with mutations in the PLP gene $[15,16]$. Accordingly, postmortem tissue shows significant neuronal loss in PMD cases with duplications of human PLP1 [13]. Many sites of neuronal loss in this disorder correspond to brain regions in transgenic mice, including neostriatum, that contain neuronal phenotypes capable of PLP promoter activation and srPLP expression [40]. Similar forms of degeneration of neostriatal projection neurons occur in spastic paraplegia type 2 [41] in association with mutations in the human PLP1 gene.

\section{Acknowledgements}

This work was supported by National Multiple Sclerosis Society pilot grant No. PP1562 (A.C.), NINDS grant RO1NS023022-23 (A.C.), and a Stein/Oppenheimer Endowment Award (D.F. and A.C.). We thank Dr. Cristina Ghiani, Donna Crandall and Dr. Ellen Carpenter for assistance.

\section{References}

1 Delaunay D, Heydon K, Cumano A, Schwab MH, Thomas JL, Suter U, Nave KA, Zalc B, Spassky N: Early neuronal and glial fate restriction of embryonic neural stem cells. J Neurosci 2008;28:2551-2562.

$\checkmark 2$ Delaunay D, Heydon K, Miguez A, Schwab M, Nave KA, Thomas JL, Spassky N, Martinez S, Zalc B: Genetic tracing of subpopulation neurons in the prethalamus of mice (Mus musculus). J Comp Neurol 2009;512: $74-83$.

3 Campagnoni CW, Garbay B, Micevych P, Pribyl T, Kampf K, Handley VW, Campagnoni AT: DM20 mRNA splice product of the myelin proteolipid protein gene is expressed in the murine heart. J Neurosci Res 1992;33:148-155.

-4 Pribyl TM, Campagnoni CW, Kampf K, Handley VW, Campagnoni AT: The major myelin protein genes are expressed in the human thymus. J Neurosci Res 1996;45:812819.
5 Pribyl TM, Campagnoni CW, Kampf K, Ellison JA, Landry CF, Kashima T, McMahon J, Campagnoni AT: Expression of the myelin basic protein gene locus in neurons and oligodendrocytes in the human fetal central nervous system. J Comp Neurol 1996;374: 342-353.

-6 Skoff RP, Bessert DA, Cerghet M, Franklin MJ, Rout UK, Nave KA, Carlock L, Ghandour MS, Armant DR: The myelin proteolipid protein gene modulates apoptosis in neural and non-neural tissues. Cell Death Differ 2004;11:1247-1257.

7 Fulton D, Paez PM, Campagnoni AT: The multiple roles of myelin protein genes during the development of the oligodendrocyte. ASN Neuro 2010;2:e00027.

-8 Bongarzone ER, Campagnoni CW, Kampf K, Jacobs EC, Handley VW, Schonmann V, Campagnoni AT: Identification of a new exon in the myelin proteolipid protein gene encoding novel protein isoforms that are restricted to the somata of oligodendrocytes and neurons. J Neurosci 1999;19:8349-8357.
9 Bongarzone ER, Jacobs EC, Schonmann V, Campagnoni AT: Classic and soma-restricted proteolipids are targeted to different subcellular compartments in oligodendrocytes. J Neurosci Res 2001;65:477-484.

10 Jacobs EC, Bongarzone ER, Campagnoni CW, Kampf K, Campagnoni AT: Soma-restricted products of the myelin proteolipid gene are expressed primarily in neurons in the developing mouse nervous system. Dev Neurosci 2003;25:96-104

11 Miller MJ, Kangas CD, Macklin WB: Neuronal expression of the proteolipid protein gene in the medulla of the mouse. J Neurosci Res 2009;87:2842-2853.

12 Mallon BS, Shick HE, Kidd GJ, Macklin WB: Proteolipid promoter activity distinguishes two populations of NG2-positive cells throughout neonatal cortical development. J Neurosci 2002;22:876-885. 
-13 Sima AA, Pierson CR, Woltjer RL, Hobson GM, Golden JA, Kupsky WJ, Schauer GM, Bird TD, Skoff RP, Garbern JY: Neuronal loss in Pelizaeus-Merzbacher disease differs in various mutations of the proteolipid protein 1. Acta Neuropathol 2009;118:531-539.

14 Mar S, Noetzel M: Axonal damage in leukodystrophies. Pediatr Neurol 2010;42:239242 .

-15 Miller M.J, Haxhiu MA, Georgiadis P, Gudz TI, Kangas CD, Macklin WB: Proteolipid protein gene mutation induces altered ventilatory response to hypoxia in the myelin-deficient rat. J Neurosci 2003;23:2265-2273.

-16 Mayer CA, Macklin WB, Avishai N, Balan K, Wilson CG, Miller MJ: Mutation in the myelin proteolipid protein gene alters $\mathrm{BK}$ and SK channel function in the caudal medulla. Respir Physiol Neurobiol 2009;169:303-314.

-17 Fulton D, Paez PM, Fisher R, Handley V, Colwell CS, Campagnoni AT: Regulation of Ltype $\mathrm{Ca}^{++}$currents and process morphology in white matter oligodendrocyte precursor cells by golli-myelin proteins. Glia 2010;58: 1292-1303.

-18 Fisher R, Boylan M: Tachykinin-immunoreactive neurons in developing feline neostriatum: somatodendritic morphogenesis demonstrated by combined immunohistochemistry/Golgi impregnation-gold toning. Dev Neurosci 2011;33:1-10.

19 Peters A, Palay SL, Webster H: The Fine Structure of the Nervous System. New York, Oxford University Press, 1991.

20 Rivers LE, Young KM, Rizzi M, Jamen F, Psachoulia K, Wade A, Kessaris N, Richardson WD: PDGFRA/NG2 glia generate myelinating oligodendrocytes and piriform projection neurons in adult mice. Nat Neurosci 2008;11:1392-1401.

-21 Zhu X, Bergles DE, Nishiyama A: NG2 cells generate both oligodendrocytes and gray matter astrocytes. Development 2008;135: 145-157.

-22 Nisenbaum ES, Wilson CJ: Potassium currents responsible for inward and outward rectification in rat neostriatal spiny projection neurons. J Neurosci 1995; 15:44494463.
23 Moe MC, Varghese M, Danilov AI, Westerlund U, Ramm-Pettersen J, Brundin L, Svensson M, Berg-Johnsen J, Langmoen IA: Multipotent progenitor cells from the adult human brain: neurophysiological differentiation to mature neurons. Brain 2005;128. 2189-2199.

24 Bergles DE, Roberts JD, Somogyi P, Jahr CE: Glutamatergic synapses on oligodendrocyte precursor cells in the hippocampus. Nature 2000;405:187-191.

25 Kemp JM, Powell TP: The structure of the caudate nucleus of the cat: light and electron microscopy. Philos Trans R Soc Lond B Biol Sci 1971;262:383-401.

26 Tepper JM, Sharpe NA, Koos TZ, Trent F: Postnatal development of the rat neostriatum: electrophysiological, light- and electron-microscopic studies. Dev Neurosci 1998;20:125-145.

27 Hurst RS, Cepeda C, Shumate LW, Levine MS: Delayed postnatal development of NMDA receptor function in medium-sized neurons of the rat striatum. Dev Neurosci 2001;23:122-134.

28 Anderson KD, Reiner A: Immunohistochemical localization of DARPP-32 in striatal projection neurons and striatal interneurons: implications for the localization of D1like dopamine receptors on different types of striatal neurons. Brain Res 1991;568:235243.

29 Bennett BD, Wilson CJ: Synaptic regulation of action potential timing in neostriatal cholinergic interneurons. J Neurosci 1998; 18: 8539-8549.

30 Plotkin JL, Wu N, Chesselet MF, Levine MS Functional and molecular development of striatal fast-spiking GABAergic interneurons and their cortical inputs. Eur J Neurosci 2005;22:1097-1108.

31 Wang DD, Krueger DD, Bordey A: Biophysical properties and ionic signature of neuronal progenitors of the postnatal subventricular zone in situ. J Neurophysiol 2003;90: 2291-2302.

32 Gallo V, Zhou JM, McBain CJ, Wright P, Knutson PL, Armstrong RC: Oligodendrocyte progenitor cell proliferation and lineage progression are regulated by glutamate receptor-mediated K+ channel block. J Neurosci 1996;16:2659-2670.
33 Verity AN, Campagnoni AT: Regional expression of myelin protein genes in the developing mouse brain: in situ hybridization studies. J Neurosci Res 1988;21:238-248.

34 Fuss B, Mallon B, Phan T, Ohlemeyer C, Kirchhoff F, Nishiyama A, Macklin WB: Purification and analysis of in vivo-differentiated oligodendrocytes expressing the green fluorescent protein. Dev Biol 2000;218:259274.

-35 Guo F, Maeda Y, Ma J, Xu J, Horiuchi M, Miers L, Vaccarino F, Pleasure D: Pyramidal neurons are generated from oligodendroglial progenitor cells in adult piriform cortex. J Neurosci 2010;30:12036-12049.

-36 Tuason M, Rastikerdar A, Kuhlmann T, Goujet-Zalc C, Zalc B, Dib S, Friedman H, Peterson A: Separate proteolipid protein/ DM20 enhancers serve different lineages and stages of development. J Neurosci 2008; 28:6895-6903.

>37 Fisher R, Hull C, Buchwald N, Adinolfi A, Levine M: The morphogenesis of glutamic acid decarboxylase in the neostriatum of the cat: neuronal and ultrastructural localization. Dev Brain Res 1987;33:215-234.

38 Fisher R, Buchwald N, Hull C, Levine M: Neurons of origin of striatonigral axons in the cat: connectivity and Golgi markers of somatodendritic architecture. Brain Res 1986;397:173-180.

39 Marin O, Anderson SA, Rubenstein JL: Origin and molecular specification of striatal interneurons. J Neurosci 2000;20:60636076.

40 Sarret C, Combes P, Micheau P, Gelot A, Boespflug-Tanguy O, Vaurs-Barriere C: Novel neuronal proteolipid protein isoforms encoded by the human myelin proteolipid protein 1 gene. Neuroscience 2010;166:522538.

-41 Saugier-Veber P, Munnich A, Bonneau D, Rozet JM, Le Merrer M, Gil R, BoespflugTanguy O: X-linked spastic paraplegia and Pelizaeus-Merzbacher disease are allelic disorders at the proteolipid protein locus. Nat Genet 1994;6:257-262. 